\title{
Penerapan Metode Technology Acceptance Model Untuk Pengukuran Tingkat Penerimaan Aplikasi SIM3LON (Sistem Mandiri LPG Online)
}

\author{
Adila Safitri* $^{1}$, Ni’mah Akbar Habibie ${ }^{2}$, Illyin Almeito ${ }^{3}$, Moh. Hasyimi ${ }^{4}$, \\ Yonathan Aditya Saputra ${ }^{5}$, Eko Sediyono ${ }^{6}$, Aris Puji Widodo ${ }^{7}$ \\ 1,2,3,4,5,6,7 Universitas Diponegoro; Jl. Prof. Soedarto, SH., Tembalang, Semarang, Jawa Tengah, \\ (024)7460020 \\ Jurusan Sistem Informasi, Sekolah Pascasarjana, Semarang \\ e-mail: *12adilasafitri@students.undip.ac.id, ${ }^{2}$ nimahakbarhabibie@ students.undip.ac.id, \\ 3illiyinalmeito@students.undip.ac.id, ${ }^{4}$ syimi0101@ students.undip.ac.id, \\ 5yoyonadit@ students.undip.ac.id, ${ }^{6}$ ekosediyono@ lecturer.undip.ac.id, ${ }^{7}$ arispw@gmail.com
}

\begin{abstract}
Abstrak: Penelitian ini dilakukan untuk pengujian terhadap penerimaan pengguna (Agen dan Pangkalan) terhadap sistem SIM3LON dengan menggunakan Technology Acceptance Model (TAM). Pengujian ini dilakukan dengan mengukur pengaruh variable Perceived Ease of Use, Perceived Usefulness dan Intention to use dengan nilai likert 1-5 dengan metode TAM. Metode pengujian yang dilakukan menggunakan tool R GUI untuk menghasilkan nilai validitas dan reliabilitas serta melakukan perhitungan menggunakan metode "korelasi product moment". Data diperoleh melalui kuesioner yang dibagikan kepada responden agn PT Catur Karya dan pangkalan. Penelitian ini menghasilkan nilai validitas rata-rata 0,77 yang berarti agen dan pangkalan merasa SIM3LON ini mudah digunakan, sedangkan nilai reliabilitasnya adalah 0,72 yang berarti agen dan pangkalan merasa sistem SIM3LON ini memberi manfaat dalam pekerjaan.
\end{abstract}

Kata kunci- Technology Acceptance Model, $\quad$ SIM3LON, $\quad$ Perceived Ease of Use, Perceived of Usefulness, Intention to Use

\begin{abstract}
In this article to see the implementation results of a system used in an organization, it is necessary to consider the acceptance of the user to the system used. This research was conducted to test user acceptance (Agent and Base) of SIM3LON system using Technology Acceptance Model (TAM). Testing in this case was done by measuring the influence of perceived ease of use and perceived usefulness variables with likert values of 1-5 with the TAM method. Testing methods performed using $R$ generate validity and reliability values. Evaluation data is obtained through questionnaires distributed to respondents of PT Catur Karya agents and their bases. This research produced an average Validity value of 0.77 which means agents and bases feel SIM3LON is easy to use, while the average value of Reliability is 0.72 which means agents and bases feel this SIM3LON system benefits in the job.
\end{abstract}

Keywords: Technology Acceptance Model, SIM3LON, Perceived Ease of Use, Perceived of Usefulness

\section{PENDAHULUAN}

Lebih dari seperempat pendapatan Indonesia tiap tahunnya berasal dari sektor minyak dan juga gas bumi. Sektor minyak dan gas bumi atau yang biasa disebut dengan sektor migas merupakan sektor produksi yang penting bagi negara dan hampir menguasai hajat hidup orang banyak sebagaimana tertulis dalam UUD 1945 pasal 33, salah satu komoditas di sektor ini yang menarik untuk dicermati adalah Liquefied Petroleum Gas (LPG) [1].

PT Pertamina adalah salah satu perusahaan dari BUMN yang menjadi ujung tombak bagi kemajuan negara Indonesia. Komitmen perusahaan untuk mengembangkan energi baru dan 
untuk menyediakan energi adalah sebuah tonggak yang dipegang dengan kokoh oleh PT Pertamina hingga masa ini. Komitmen perusahaan ini dapat dibuktikan dengan menciptakan produk-produk yang berkualitas agar kebutuhan konsumen dapat terpenuhi. Pertamina mengelola energi konvensional dan pengembangan energi baru dan terbarukan, secara operasional pelaksanaan pengelolaan dan pengembangan energi dilakukan oleh subholding perusahaan diantaranya upstream subholding, gas subholding, refining \& petrochemical subholding, power \& NRE subholding, dan commercial \& trading subholding. Selain itu diluar pengelolaan operasional, PT Pertamina juga mengelola jaringan distribusi LPG yang terintegrasi di seluruh Indonesia melalui fungsi logistik dan infrastruktur dengan merek dagang LPG.

Perkembangan teknologi yang sangat pesat dapat mendorong perubahan perilaku masyarakat dalam merubah dan menciptakan peluang bisnis. Sehingga terjadi pertukaran informasi secara elektronik, dengan menggunakan jaringan internet oleh para pelaku bisnis ke aplikasi penjualan, pemasaran, strategi bisnis juga pelayanan terhadap pelanggan.

PT Pertamina memanfaatkan teknologi sistem informasi SIM3LON (Sistem Mandiri LPG Online) untuk mengelola pendistribusian LPG. Penggunaan aplikasi SIM3LON dapat menyajikan informasi yang distribusikan LPG oleh agen menjadi jelas, dengan cara mengetahui lokasi mana yang menggunakan gas LPG. Sehingga, PT Pertamina dapat mengefisienkan kuota gas LPG pada setiap agen di wilayah tersebut, dengan harapan proses pendistribusian gas menjadi lebih cepat dan akurat sehingga agen dapat bekerja lebih efektif serta efisien [2].

Berdasarkan latar belakang diatas, diperlukan analisis tingkat penerimaan oleh pengguna untuk mengetahui sistem informasi SIM3LON tersebut meningkatkan kinerja dalam bekerja dan kemudahan penggunaan aplikasi dari sisi pengguna menggunakan metode Technology Acceptance Model (TAM).

\section{METODE PENELITIAN}

PT Catur Karya, Salatiga, Kabupaten Semarang merupakan tempat penelitian yang akan dilakukan. Dalam penelitian ini, responden yang berpartisipasi yaitu agen dan pangkalan. Sedangkan waktu penelitian dilakukan selama satu minggu terhitung dari kuesioner dibagikan. Pada proses penelitian ini yang menjadi populasi yaitu agen dan pangkalan, untuk sampel agen dan pangkalan akan ditentukan berupa metode pengambilan sampel berdasarkan pertimbanganpertimbangan yang berfokus pada tujuan tertentu. Sampel-sampel yang diambil dalam penelitian ini adalah berjumlah 42 responden yang aktif menggunakan sistem SIM3LON.

\subsection{Kajian Pustaka}

\subsection{SIM3LON (Sistem Mandiri LPG Online)}

SIM3LON adalah aplikasi sistem mandiri LPG Online, yaitu yang digunakan untuk memudahkan pemesanan dan pencatatan LPG $3 \mathrm{~kg}$ dari pangkalan ke agen. Pangkalan diharuskan menandatangani perjanjian kerja sama antara SIM3LON dengan SIMOL3K Pertamina. Keunggulan sistem ini adalah juga dapat membantu mengontrol kuota subsidi LPG 3 $\mathrm{kg}$ yang telah ditetapkan, sekaligus mencatat seluruh transaksi. SIM3LON ini juga dapat memantau pengiriman barang hingga ke pangkalan secara sistem. Pertukaran informasi dari sistem ini adalah laporan transaksi harian dan bulanan dari pangkalan ke agen. Tampilan dari sistem SIM3LON ini dapat dilihat pada Gambar 1.

Adilaet, al., (Penerapan Metode Technology Acceptance Model Untuk Pengukuran Tingkat Penerimaan Aplikasi SIM3LON (Sistem Mandiri LPG Online) 


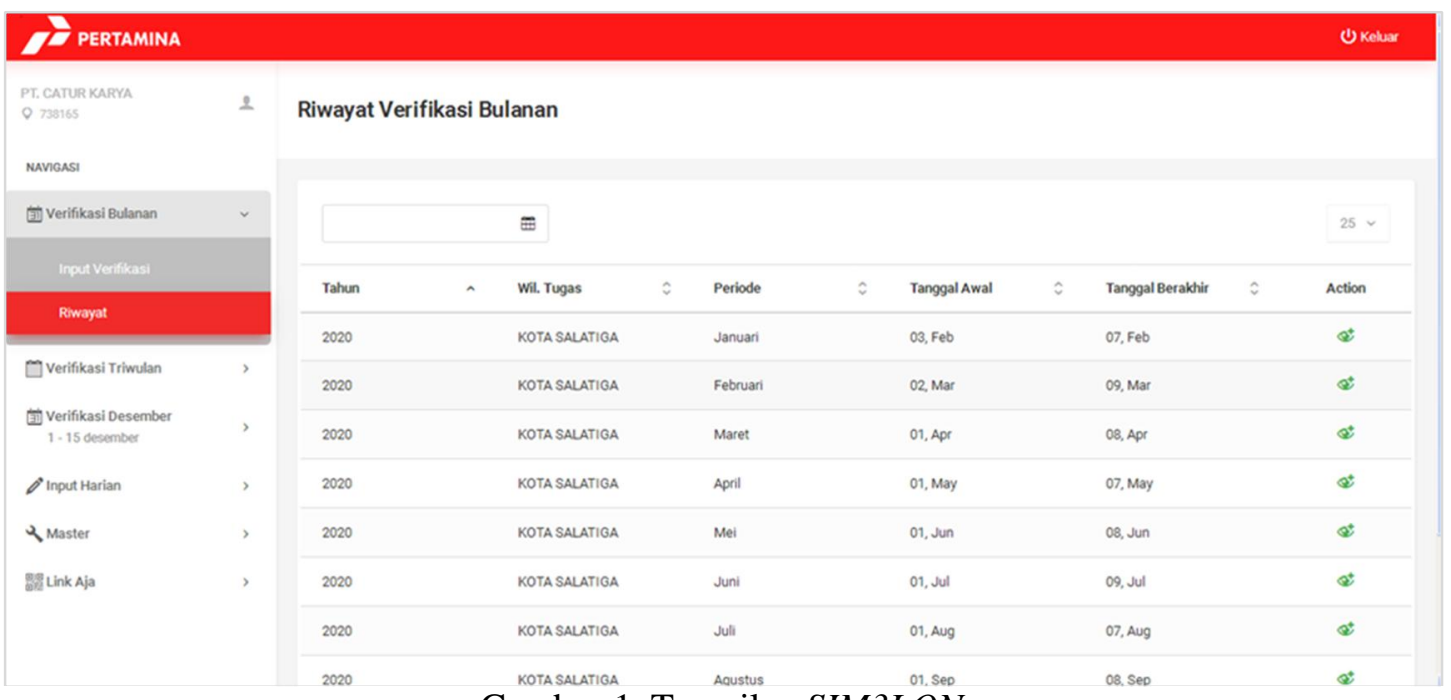

Gambar 1 Tampilan SIM3LON

Pada sistem SIM3LON ini, terdapat beberapa isi diantaranya verifikasi bulanan, verifikasi, triwulan, verifikasi Desember, input harian, dan master. Bagian verifikasi bulanan berisikan penginputan data transaksi dari pangkalan tiap bulan. Karena pangkalan rata-rata tidak sempat melakukan penginputan data di SIM3LON, maka dari pangkalan menggunakan logbook sebagai data transaksi yang nantinya diserahkan ke pihak agen, dari pihak agen yang akan input data transaksi tersebut ke sistem SIM3LON. Isi dari verifikasi bulanan tersebut terdapat nomor pangkalan, nama pangkalan, stok awal, jumlah kuota penerimaan, jumlah kuota penyaluran, dan stok akhir. Verifikasi bulanan ini di input pada awal bulan, yaitu pada tanggal 1 sampai 3. Pada verifikasi triwulan berisikan penginputan data transaksi dari pangkalan tiap 3 bulan sekali. Namun, sangat jarang dilakukan update data di bagian verifikasi triwulan ini dikarenakan Pertamina lebih terfokus pada verifikasi bulanan. Pada verifikasi Desember, verifikasi ini bisa disebut sebagai verifikasi tahunan dari bulan Januari sampai Desember.

Bagian input harian terdapat harga kecamatan dan stok pangkalan. Pada harga kecamatan adalah harga sesuai HET (Harga Eceran Tertinggi) Gubernur atau Pemda setempat. Selanjutnya pada stok pangkalan, ini terdapat jumlah menyeluruh stok pangkalan tiap harinya. Terdapat penjualan 1, stok sore, penjualan 2, dan stok akhir.

Penjualan 1 adalah jumlah kuota yang diterima oleh pangkalan pada pagi hari. Jika stok masih tersisa, akan dimasukkan pada jumlah stok sore. Bagian master yaitu adalah bagian datadata dari pangkalan yang terdaftar pada agen PT. Catur Karya. Terdapat 49 pangkalan yang terdaftar. Pada bagian master berisikan ID registrasi pangkalan, nama pangkalan, kota pendaftaran pangkalan, dan status pangkalan tersebut (aktif/non aktif).

\subsubsection{Metode TAM (Technology Acceptance Model)}

TAM atau Technology Acceptance Model merupakan sebuah model untuk mengetahui seberapa besar sebuah sistem/aplikasi yang digunakan berdampak pada pengguna [3]. Pada tahun 1975 - 1980 sebelum model TAM ditemukan, Martin Fishbein dan Icek Ajzen mengembangkan teori Theory of Reasoned Action (TRA). TRA lebih memfokuskan pada sikap pengguna sistem dari sudut pandang serebral.

Tahun 1986, Davis dalam disertasinya yang mengakomodasi metode TRA, mempublikasikan hasil penelitian di Management Information Systems Quarterly (MIS 
Quarterly), yang kemudian mencetuskan teori TAM. Teori TAM memfokuskan kemudahan pada penggunaan dan kebermanfaatan untuk melakukan prediksi sikap pengguna dalam mengambil sikap dalam menggunakan sistem informasi, dalam hal ini jika diterapkan teori TAM menjadi lebih baik daripada TRA.

Dalam mempelajari suatu proses teknologi informasi yang digunakan, TAM menggunakan pendekatan teori perilaku (behavioral theory) [4]. Suatu model yang bagus itu selain melakukan prediksi, tetapi harus bisa menjelaskan. Model TAM dapat mengukur penerimaan sistem informasi dari sisi pengguna sebagai objeknya. Oleh karena itu, TAM mampu menjelaskan aplikasi SIM3LON yang digunakan di agen dan pangkalan Elpiji sudah sesuai yang diharapkan oleh pengguna atau belum. Dengan metode TAM dapat memberikan informasi tentang pengaruh faktor eksternal terhadap keyakinan, tujuan dan sikap dari penggunanya aplikasi. Yang menjadi kelebihan dari metode TAM adalah dapat menjadi jawaban apakah aplikasi SIM $3 L O N$ berhasil atau tidak diterima di setiap agen dan sub-agen atau pangkalan pada penelitian ini.

\subsection{Teknik Pengumpulan Data}

Penelitian ini memakai 3 (tiga) variabel model TAM. yaitu: variabel Persepsi Kebermanfaatan (Perceived Usefulness) menjadi variabel $\left(\mathrm{X}_{1}\right)$ dan variabel Kemudahan Penggunaannya (Perceived Ease of Use) menjadi variabel $\left(\mathrm{X}_{2}\right)$ dan penerimaan penggunaan SIM3LON sebagai variabel (Y) [5]. Dalam hal ini teori TAM secara signifikan berpengaruh terhadap seberapa besar bentuk penerimaan pengguna atau user yaitu agen dan pangkalan sebagai penggunan aplikasi SIM3LON.

Pada penelitian kali ini, metode riset pengujian hipotesis yaitu membuat sebuah hipotesis yang berlandaskan merujuk dari beberapa penelitian yang sesuai dengan penelitian ini. Kuesioner adalah metode yang digunakan untuk mengumpulkan dan memperoleh data dari target-target responden yang terpilih, yaitu agen dan sub-agen/pangkalan. Dari data tersebut hal yang kami lakukan selanjutnya adalah merumuskan hipotesis dilanjutkan dengan memproses data, melakukan analisis serta yang terakhir yaitu melakukan interpretasi. Setelah data tersebut dianalisis, kemudian dari hasil yang ada harus dilakukan interpretasi awal dari hasil analisis sementara.

Objektivitas, validitas, serta seberapa besar data tersebut dapat dipercaya, penelitian akan menggunakan data yaitu hasil kuesioner sebagai acuan, yaitu data yang diperoleh langsung dari hasil responden berupa penyebaran kuesioner kepada agen dan pangkalan yang aktif dalam menggunakan sistem SIM $3 L O N$ terpilih sebagai sampel tersebut. Pada kuesioner yang disebarkan ini aka nada pengelompokan berdasarkan pertanyaan-pertanyaan yang nantinya menjadi pengukur dalam pengerjaan penelitian ini. Pengelompokan kuesioner tersebut berdasarkan variabel-variabel antara lain yaitu berdasarkan kemudahan penggunaannya, persepsi kebermanfaatannya, dan penerimaan sistemnya. Untuk validitas yang digunakan sebagai alat ukur penelitian adalah validitas yang berisikan poin-poin pertanyaan yang sudah disusun berdasarkan definisi dari beberapa variabel yang akan menjadi ukurannya nanti.

Tabel 1. Definisi dan Dimensi Penerimaan Penggunaan Teknologi [6]

\begin{tabular}{lll}
\hline Dimensi & Definisi & Indikator \\
\hline
\end{tabular}




\begin{tabular}{|c|c|c|}
\hline $\begin{array}{l}\text { Perceived of Usefulness } \\
\text { (POU) sebagai variabel } \\
X_{1}\end{array}$ & $\begin{array}{l}\text { Tingkat sejauh mana pengguna } \\
\text { merasa percaya teknologi yang } \\
\text { digunakan meningkatkan } \\
\text { kinerja }\end{array}$ & $\begin{array}{ll}\text { - } & \text { Bermanfaat } \\
\text { - } & \text { Efektivitas } \\
\text { Produktivitas }\end{array}$ \\
\hline $\begin{array}{l}\text { Perceived Ease of Use } \\
\text { (PEU) sebagai variabel } \\
\mathbf{X}_{2}\end{array}$ & $\begin{array}{l}\text { Tingkat seorang pengguna } \\
\text { merasa percaya teknologi } \\
\text { tersebut dapat digunakan } \\
\text { dengan mudah dan tidak ada } \\
\text { masalah. }\end{array}$ & $\begin{array}{ll}\text { - } & \text { Mudah dipelajari } \\
\text { - } & \text { Mudah dipahami } \\
\text { - } & \text { Fleksibelitas } \\
\text { - } & \text { Kemudahan mencapai } \\
& \text { tujuan } \\
\text { - } & \text { Kemudahan untuk } \\
& \text { digunakan }\end{array}$ \\
\hline $\begin{array}{l}\text { Intention to Use (ITU) } \\
\text { (Y) }\end{array}$ & $\begin{array}{l}\text { Tingkat penerimaan pengguna } \\
\text { dalam menggunakan teknologi } \\
\text { SIM3LON }\end{array}$ & $\begin{array}{ll}\text { - } & \text { Menggunakan sistem } \\
\text { secara sebenarnya } \\
\text { - } & \text { Seringnya penggunaan } \\
\end{array}$ \\
\hline
\end{tabular}

\section{3 Teknik Analisis Data}

Analisis data pada penelitian ini menggunakan program $\mathrm{R}$ dengan uji kualitas data menggunakan uji validitas dan reliabilitas serta pengujian regresi linear berganda.

\subsubsection{Pengujian Validitas}

Dalam mengukur variabel penelitian yang valid dari hasil pertanyaan yang telah diajukan maka dilakukan Uji Validitas. Uji validitas bisa dilihat nilai signifikan masing-masing instrumen [7]. Data dari masing - masing pertanyaan dapat dihitung nilai korelasi dengan jumlah keseluruhan memamfaatkan rumus teknik korelasi product moment, sebagai berikut:

$$
\frac{n \sum X Y-\left(\sum X\right)\left(\sum Y\right)}{\left.\sqrt{\left\{n \sum X^{2}\right.}-\left(\sum X\right)^{2}\right\}\left\{n \sum Y^{2}-\left(\sum Y\right)^{2}\right\}}(1)
$$

Keterangan:

r $\quad$ : nilai korelasi

n : jumlah responden

$\mathrm{X} \quad$ : skor setiap item

Y : skor total

$\mathrm{XY} \quad$ : skor setiap item $\mathrm{x}$ skor total

$\sum Y^{2} \quad$ : jumlah kuadrat skor total

$\sum X^{2} \quad$ : jumlah kuadrat skor item

$\left(\sum Y\right)^{2}:$ kuadrat jumlah skor total

$\left(\sum X\right)^{2}$ : kuadrat jumlah skor item

\section{3.2 Pengujian Reliabilitas}

Pengujian reliabilitas menggunakan kriteria CA (Cronbach's Alpha) untuk mengukur ketetapan jawaban responden [6]. Bila alat ukur telah valid maka akan dilakukan pengujian. Instrumen reliabilitas mencari beberapa nilai sehingga skor yang didapat bukan 0-1. Dalam perhitungan pengujian ini, digunakan skor 1 sampai dengan 5. Berikut adalah merupakan uji reliabilitas: 


$$
r_{11}=\left(\frac{k}{k-1}\right)\left(\frac{\sum a_{p^{2}}}{a_{t^{2}}}\right)
$$

Keterangan:

$r_{11} \quad:$ Reliabilitas instrument

$\mathrm{k} \quad$ : Banyak butir pertanyaan

$a_{t^{2}} \quad$ : Deviasi standar total

$\sum a_{t^{2}} \quad$ : Jumlah deviasi standar butir

Selanjutnya, menghitung nilai varians tiap butir untuk menentukan jumlah varians butir:

Keterangan:

$$
\propto^{2}=\frac{\sum X^{2}-\frac{\left(\sum X\right)^{2}}{n}}{n}
$$

$\mathrm{n} \quad$ : jumlah responden

$\mathrm{x} \quad$ : nilai skor yang dipilih dari butir pertanyaan

\subsubsection{Uji Regresi Linear Berganda}

Uji statistik dengan menggunakan metode regresi linear berganda berguna untuk melakukan pengujian hipotesis. Analisis regresi linear berganda digunakan untuk melihat pengaruh antara satu variabel dan variabel yang lain. Variabel independen yang digunakan dalam penelitian ini yaitu lebih dari satu variabel yaitu variabel kemudahan dan variabel kebermanfaatan terhadap penerimaan SIM3LON. Untuk variabel dependen menggunakan satu variabel yaitu adalah variabel penerimaan. Berikut adalah rumus persamaan regresi berganda:

Keterangan:

$$
Y=a+b_{1} x_{1}+b_{2} x_{2}+e(4)
$$

$\begin{array}{ll}\mathrm{Y} & : \text { Penerimaan sistem SIM3LON } \\ \mathrm{A} & : \text { Konstanta } \\ b_{1} b_{2} & : \text { Koefisien regresi } \\ x_{1} & : \text { Variabel kebermanfaatan } \\ x_{1} & : \text { Variabel kemudahan } \\ \mathrm{e} & : \text { Error }\end{array}$

\section{HASIL DAN PEMBAHASAN}

Berdasarkan hasil dari penelitian yang didapatkan dari kuesioner yang sudah dibagikan kepada responden agen dan pangkalan yang berada di PT Catur Karya, kemudian dilakukan pengujian untuk mengukur penerimaan sistem SIM3LON yaitu dengan melakukan analisis validitas dan reliabilitas. Hasil dari jawaban para responden diukur dengan menggunakan skala likert 1 sampai 5 . Angka 1 yaitu berarti ketidakpuasan responden dan angka 5 berarti kepuasan responden atas pertanyaan seputar SIM3LON.

Variabel Perceived Ease of Use (PEU) atau mengenai kemudahan dalam menggunakan sistem SIM3LON yaitu diukur dengan 5 pertanyaan/pernyataan. Berdasarkan data tabel diatas, nilai minimal yang didapat pada variabel PEU adalah sebesar 3, yaitu pengguna memberikan respon paling rendah dengan angka 3 atau netral atau tidak berpengaruh. Nilai maksimumnya adalah dengan angka 5 , berarti pengguna menyatakan sangat setuju terhadap pertanyaan pada 
kuesioner. Berdasarkan dari hasil kuisioner pada pertanyaan seputar variabel PEU, nilai ratarata variabel PEU adalah sebesar 0,79 atau $79 \%$ yang artinya pengguna menyatakan setuju terhadap pertanyaan atau pernyataan yang diajukan. Setuju dalam artian bahwa pengguna merasa sistem SIM3LON ini mudah untuk digunakan oleh user.

Variabel Perceived of Usefulness (POU) atau mengenai kebermanfaatan dari sistem SIM $3 L O N$ dalam hal ini diukur pula dengan 5 pertanyaan atau pernyataan. Berdasarkan data tabel diatas, nilai minimal yang didapat pada variabel POU adalah angka 3, yaitu pengguna memberikan repon paling rendah pada angka 3 atau netral/tidak berpengaruh. Nilai maksimal adalah angka 5, yang berarti pengguna angat setuju terhadap pertanyaan atau pernyataan pada kuesioner yang disebarkan. Rata-rata dari nilai variabel POU adalah sebesar 0,72 atau $72 \%$ yang artinya pengguna menyatakan setuju terhadap pertanyaan yang diajukan. Setuju dalam artian bahwa responden merasa sistem SIM3LON ini memberi manfaat dalam pekerjaan Agen serta Pangkalan sebagai pengguna.

Variabel Intention of Use (ITU) atau penerimaan SIM3LON dalam pekerjaan diukur dengan 3 pertanyaan. Berdasarkan hasil dari jawaban responden, nilai minimal pada variabel ITU adalah sebesar 3, yaitu responden memberikan jawaban paling rendah pada angka 3 atau netral alias tidak berpengaruh. Nilai maksimum adalah sebesar 5, yang berarti responden sangat setuju terhadap pertanyaan pada kuesioner. Berdasarkan dari hasil kuesioner pada pertanyaan seputar variabel ITU, nilai variabel ITU sebesar 0,77 (77\%) yang artinya responden setuju terhadap pertanyaan yang diberikan. Setuju dalam artian bahwa responden merasa SIM3LON ini dapat diterima dalam pekerjaan.

Dalam penelitian ini, data didapatkan dengan cara menyebar kuesioner pada responden SIM3LON. Jumlah responden yang mengisi kuesioner adalah sebanyak 42 responden. Analisis dalam penelitian ini yaitu dengan melakukan dua pengujian, yaitu uji kualitas data menggunakan uji validitas dan uji reliabilitas [8].

\subsection{Uji Validitas dan Reliabilitas}

Tabel 2. Data Kuesioner

\begin{tabular}{|c|c|c|c|c|c|c|c|c|c|c|c|c|c|c|c|c|c|c|}
\hline $\boldsymbol{\Delta}$ & PEU1 & & PEU2 & 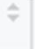 & PEU3 & 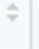 & PEU4 & $\hat{*}$ & PEU5 & 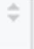 & POU1 & 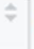 & POU2 & & POU3 & POU4 & 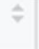 & Pous \\
\hline 1 & 3 & 3 & & 3 & & 3 & & 3 & & 3 & & 3 & 3 & $\beta$ & & & 3 & 3 \\
\hline 2 & 5 & 5 & & 5 & & 4 & & 4 & & 5 & & 5 & 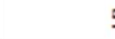 & 5 & & & 4 & 5 \\
\hline 3 & 2 & 4 & & 5 & & 4 & & 4 & & 3 & & 4 & 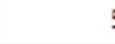 & 5 & & & 4 & 4 \\
\hline 4 & 2 & 4 & & 4 & & 5 & & 5 & & 4 & & 4 & 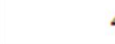 & 4 & & & 5 & 5 \\
\hline 5 & 2 & 4 & & 5 & & 3 & & 3 & & 4 & & 5 & 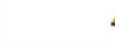 & 4 & & & 5 & 5 \\
\hline 6 & 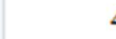 & 4 & & 4 & & 4 & & 5 & & 5 & & 4 & 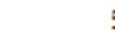 & 5 & & & 4 & 4 \\
\hline
\end{tabular}

Dari data hasil kuesioner seperti Tabel 2, selanjutnya data tersebut diolah menggunakan RStudio untuk menentukan kualitas data menggunakan uji validitas dan juga uji reliabilitas. Uji validitas yaitu dilakukan dengan mengkorelasikan nilai tiap-tiap pernyataan dengan nilai total, dan standar koefisien korelasi > 0,5 [9]. Jika nilai dari koefisien korelasi adalah > 0,5 maka dapat dinyatakan bahwa data atau pertanyaan dalam kuesioner tersebut valid [10]. Hasil dari pengujian menggunakan uji validitas dapat dilihat pada tabel 3:

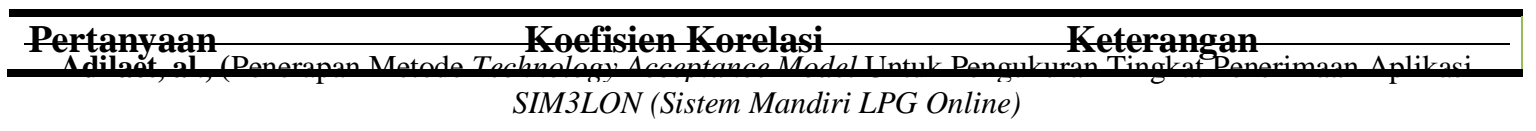




\begin{tabular}{lll}
\hline PEU1 & 0,64 & Valid \\
\hline PEU2 & 0,75 & Valid \\
PEU3 & 0,68 & Valid \\
\hline PEU4 & 0,68 & Valid \\
\hline PEU5 & 0,42 & Valid \\
\hline POU1 & 0,64 & Valid \\
\hline POU2 & 0,53 & Valid \\
\hline POU3 & 0,53 & Valid \\
\hline POU4 & 0,43 & Valid \\
\hline ITU1 & 0,68 & Valid \\
\hline ITU2 & 0,69 & Valid \\
\hline ITU3 & 0,75 & Valid \\
\hline
\end{tabular}

Tabel 3. Uji Validitas Data

Berdasarkan dari uji kualitas data pada Tabel 3 pada bagian Uji Kualitas Data menggunakan software $\mathrm{R}$, dapat dinyatakan bahwa semua pertanyaan dalam kuesioner yaitu dari pertanyaan no 1 sampai 13 adalah valid. Dinyatakan valid dikarenakan nilai koefisien korelasi atau nilai $\mathrm{R}$ total masing-masing pertanyaan $>=0,3$. Selanjutnya, untuk uji reliabilitas dapat menggunakan teknik uji CA (Cronbach's Alpha) dimana uji ini dilakukan secara keseluruhan atau bersama-sama dari butir-butir pertanyaan. Pertanyaan dalam kuesioner dinyatakan reliabel jika memiliki nilai Cronbach's Alpha > 0,6.

Tabel 4. Uji reliabilitas

\begin{tabular}{llll}
\hline Variabel & Cronbach's Alpha & Signifikan & Keterangan \\
\hline Perceived Ease of Use & 0,79 & 0,6 & Reliabel \\
\hline Perceived of Usefulness & 0,72 & 0,6 & Reliabel \\
\hline Intention to Use & 0,77 & 0,6 & Reliabel \\
\hline
\end{tabular}

Berdasarkan pengolahan data dari uji reliabilitas pada Tabel 4 menggunakan software R, maka didapatkan hasil Cronbach's Alpha dari variabel PEU adalah 0,79 yaitu lebih dari nilai signifikan 0,6 yang artinya variabel tersebut reliabel. Hasil cronbach's alpha dari variabel POU adalah sebesar 0,72 yaitu lebih dari nilai signifikan 0,6 yang artinya variabel tersebut reliabel, dan hasil cronbach's alpha dari variabel ITU adalah sebesar 0,77 yaitu lebih dari nilai signifikan 0,6 yang artinya variabel tersebut reliabel. Dari ketiga variabel tersebut, dikarenakan cronbach's alpha > 0,6 maka seluruh variabel dinyatakan reliabel atau konsisten dalam waktu pengukuran yang berbeda.

Berdasarkan hasil yang yang diperoleh melalui uji validitas dan reliabilitas dari 13 pertanyaan tersebut, didapatkan kesimpulan bahwa seluruh pertanyaan pada kuesioner ini dinyatakan valid dan sudah reliabel sehingga sudah layak untuk digunakan dalam penelitian. Selanjutnya untuk hengujian hipotesis dalam penelitian ini, digunakan uji asumsi klasik dan regresi linear berganda. Uji asumsi klasik adalah hal yang harus dilakukan dalam analisis regresi linear berganda. Uji asumsi klasik memiliki 4 uji, yaitu uji normalitas, multikolinearitas, autokorelasi, dan heteroskedastisitas. 


\subsection{Uji Normalitas}

Uji normalitas data adalah pengujian untuk mengetahui apakah pada model regresi linear ini berdistribusi normal atau tidak dari tiap variabel bebas (independen) dan variabel terikat (dependen). Untuk mengetahui normal atau tidaknya dapat dilakukan dengan pengujian normalitas menggunaakn One-Sample Kolmogorov-Smirnov test. Tingkat signifikasi dari uji normalitas adalah 0,05 . Jika $\mathrm{H}_{0}$ diterima berarti data terdistribusi normal, jika probabilitas signifikan $<0,05$ maka $\mathrm{H}_{0}$ ditolak berarti data terdistribusi tidak normal. Berdasarkan hasil yang diperoleh pada gambar 2, didapatkan hasil bahwa signifikan atau p-value yaitu bernilai 0,84 yang mana berarti $\mathrm{H}_{0}$ diterima dikarenakan $0,84>0,05$ dan data terdistribusi dengan normal.

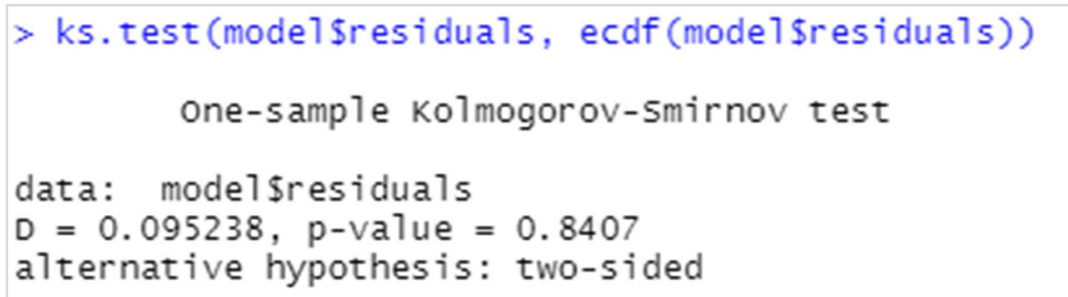

Gambar 2 Hasil uji normalitas

\subsection{Uji Moltikolinearitas}

Uji Multikolinearitas adalah pengujian pada model regresi linear ini terdapat atau tidak korelasi dari tiap variabel independen (bebas) dan variabel dependen (terikat). Untuk mengetahui ada atau tidaknya multikolinearitas pada regresi linear ini, dapat dilihat dari nilai toleransi dari VIF. VIF adalah singkatan dari Variance Inflation Factor. Nilai toleransi digunakan untuk mengukur variabel independen (bebas) yang terpilih yang tidak dapat dijelaskan oleh variabel-variabel bebas lainnnya. Tingkat signifikasi dari uji multikolinearitas adalah $0,05 . \mathrm{H}_{0}$ ditolak jika terdapat nilai VIF yang melebihi 5 maka tidak terdapat multikolinearitas antar variabel independent (bebas). Jika VIF $<5$ maka $\mathrm{H}_{1}$ diterima yaitu terdapat multikolinearitas antar variabel independen.

Berdasarkan dari hasil VIF pada Gambar 3, dari semua variabel bebas, diperoleh hasil bahwa semua nilai VIF $<5$ artinya $\mathrm{H}_{0}$ tidak ditolak dalam artinya tidak ditemukannya multikolinearitas antara variabel independen (bebas).

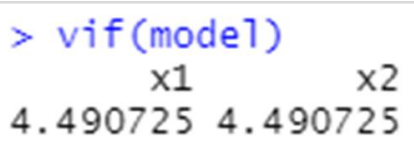

Gambar 3 Hasil uji multikolinearitas

\subsection{Uji Autokorelasi}

Uji Autokorelasi adalah pengujian pada model regresi linear ini terdapat atau tidak autokorelasi dari tiap variabel independen (bebas) dan variabel dependen (terikat). Model regresi yang baik adalah jika model dari penelitian tersebut bebas autokorelasi atau tidak terdapat autokorelasi didalamnya. Untuk mengetahui terdapat atau tidak autokorelasi, dilakukan pengujian melalui Durbin-Watson test (DWtest). Tingkat signifikansi dari uji autokorelasi ini adalah sebesar 0,05. Daerah kritis dari pengujian ini adalah $\mathrm{H}_{0}$ tidak diterima jika p-value <

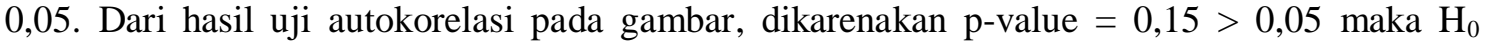
diterima artinya tidak terdapat autokorelasi pada penelitian ini atau pada data. 


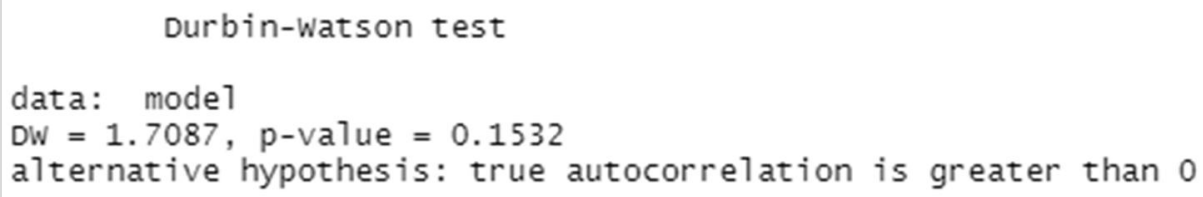

Gambar 4 Hasil Uji Autokorelasi

\subsection{Uji Heteroskedastisitas}

Uji heteroskedastisitas adalah sebuah pengujian yang memiliki tujuan guna mengetahui apakah pada model regresi ini terjadi perbedaan varians dari residual dari beberapa pengamatan yang dilakukan. Jika varians pada residual antara satu pengamatan dengan pengamatan yang lain hasilnya berbeda, maka disebut heteroskedastisitas. Model regresi dapat dikatakan baik apabila tidak terjadi heteroskedastisitas. Untuk mengetahui terdapat atau tidaknya autokorelasi, dapat dilakukan melalui Breusch-Pagan test (BPtest). Tingkat signifikansi dari uji heteroskedastisitas ini adalah sebesar 0,05. Daerah kritis dari pengujian ini adalah $\mathrm{H}_{0}$ ditolak jika p-value $<0,05$. Dari hasil uji autokorelasi pada Gambar 5, dikarenakan p-value $=0,33>$ 0,05 maka $\mathrm{H}_{0}$ diterima artinya tidak terjadi heterokedastisitas pada penelitian ini atau pada data.

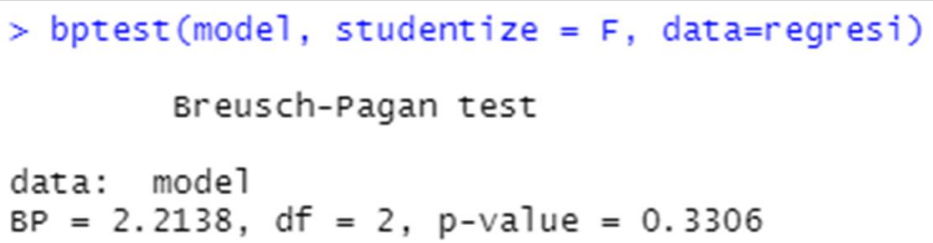

Gambar 5. Hasil Uji Heteroskedastisitas

\subsection{Uji Regresi Linear Berganda}

Regresi linear berganda dilakukan dikarenakan terdapat beberapa variabel bebas dalam memprediksi satu variabel bebas atau variabel terikat. Berdasarkan dari hasil perhitungan regresi linear berganda, didapatkan hasil regresi linear berganda yaitu:

Keterangan:

$$
Y=0,76+0,58 X_{1}+0,26 X_{2}(5)
$$

Y : Intention to Use (ITU) 


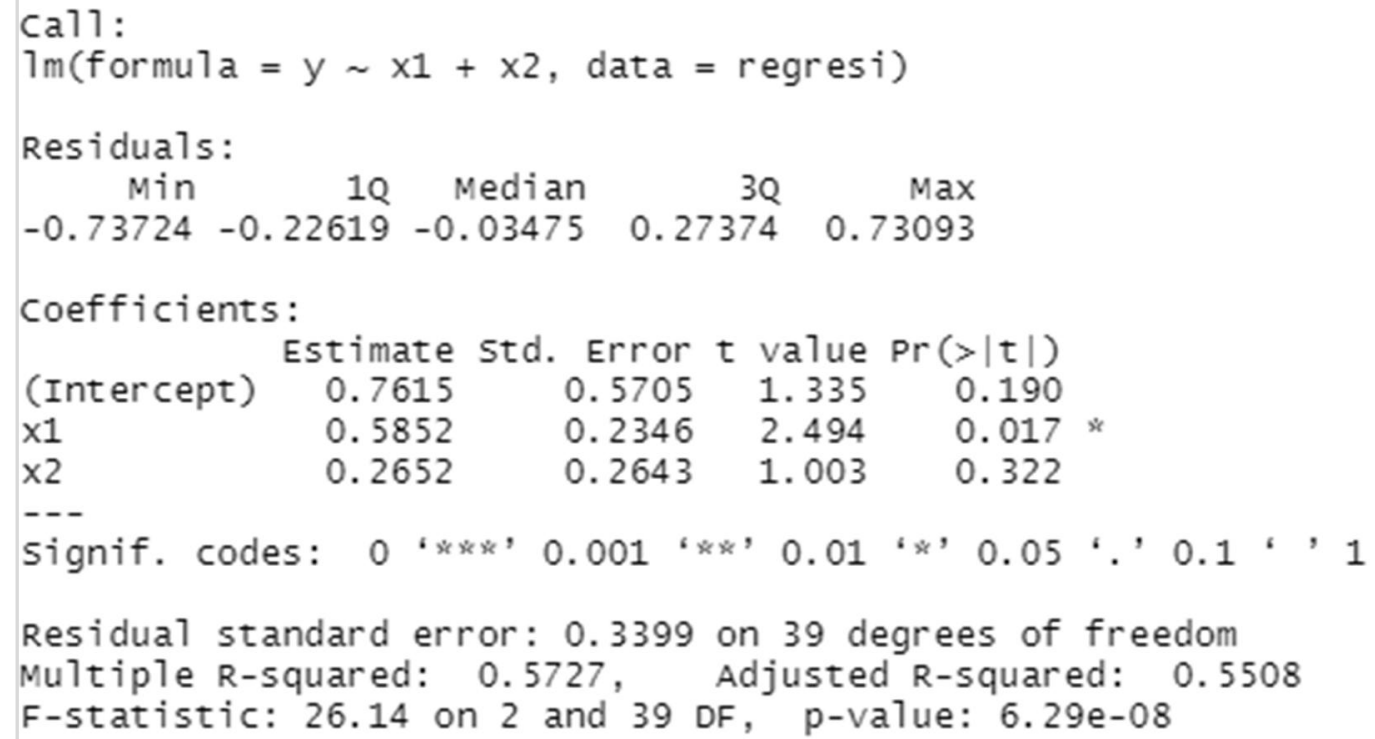

Gambar 5 Hasil uji heteroskedastisitas

Berdasarkan dari hasil persamaan tersebut, seluruh variabel bebas dari koefisien regresi yaitu bernilai positif. Dengan hasil variabel PEU $\left(\mathrm{X}_{1}\right)$ atau kemudahan sebesar 0,58 dan nilai variabel POU $\left(\mathrm{X}_{2}\right)$ yaitu sebesar 0,26. Berdasarkan dari hasil tersebut, semua variabel bebas mempunyai hubungan positif atau searah dengan variabel terikatnya. Berdasarkan hasil kedua variabel bebas tersebut, yang memberikan pengaruh lebih dominan adalah variabel PEU atau kemudahan dengan koeifisien regresinya sebesar 0,58.

\subsubsection{Uji F}

Dalam perhitungan, didapatkan hasil yaitu uji $\mathrm{F}$ dan uji $\mathrm{T}$. Uji $\mathrm{F}$ tersebut bertujuan untuk mengetahui apakah variabel bebas secara bersamaan memiliki pengaruh terhadap variabel terikatnya. Dari hasil perhitungan, nilai uji F adalah sebesar 26,14 dengan p-value < 0,01, sehingga didapatkan kesimpulan yaitu variabel kemudahan dan kebermanfaatan sama-sama berperan terhadap variabel penerimaan SIM3LON.

\subsubsection{Uji T}

Berdasarkan dari hasil uji $\mathrm{T}$, didapatkan hasil bahwa nilai uji $\mathrm{T}$ dari variabel PEU adalah 2,49 dan koefisien regresinya yaitu 0,58 . Pada nilai $\mathrm{T}$ dari variabel POU adalah 1,00 dan koefisien regresinya adalah 0,26 . Dari kedua variabel tersebut kemudian dilakukan uji signifikansi dengan hasil bahwa hanya variabel PEU yang signifikan $(\mathrm{p}<0,01)$. Sedangkan variabel POU tidak signifikan $(\mathrm{p}>0,05)$. Berdasarkan uji signifikansi tersebut, hanya variabel kemudahan saja yang berpengaruh secara individual terhadap variabel penerimaan.

Berdasarkan dari besarnya koefisien korelasi hasil perhitungan, maka nilai dari koefisien korelasi atau nilai dari multiple $R$-squared $\left(\mathrm{R}^{2}\right)$ adalah 0,57 . Berdasarkan hasil tersebut dapat diartikan bahwa variabel bebas atau PEU dan POU mampu menjelaskan 57\% dari variabel terikat atau Intention to Use (ITU). Sedangkan 43\% lainnya dijelaskan oleh variabel lain. 


\section{KESIMPULAN}

Berdasarkan dari hasil penelitian, dapat disimpulkan sebagai berikut:

1. SIM $3 L O N$ pada pengguna yaitu dari agen dan pangkalan di PT Catur Karya dipengaruhi oleh tiga faktor, yaitu adalah Perceived Ease of Use (PEU) dan Perceived of Usefulness (POU), dan Intention to Use (ITU).

2. SIM $3 L O N$ ini dipengaruhi oleh kemudahan penggunaan (PEU) SIM3LON yaitu diukur dengan lima pertanyaan dengan 42 koresponden. Dengan hasil sebesar $77 \%$ yang dapat dinyatakan bahwa variabel PEU berpengaruh pada penerimaan SIM3LON terhadap pengguna.

3. SIM3LON ini pengaruhi oleh kemudahan manfaat SIM3LON dalam pekerjaan (POU) yaitu diukur dengan lima pertanyaan dengan 42 koresponden. Dengan hasil sebesar $72 \%$ yang dapat dinyatakan bahwa variabel POU berpengaruh pada penerimaan SIM3LON terhadap pengguna.

4. SIM $3 L O N$ ini dipengaruhi oleh penerimaan sistem dalam pekerjaan (ITU) yaitu diukur dengan tiga pertanyaan dengan 42 koresponden. Dengan hasil sebesar $77 \%$ yang dapat dinyatakan bahwa variabel ITU berpengaruh pada penerimaan SIM3LON terhadap pengguna.

Dapat diketahui bahwa hasil dari penelitian ini yaitu pengguna aplikasi SIM3LON menerima penerapan aplikasi dan merasakan banyak manfaat bagi pengguna dalam melakukan pekerjaan agar membantu mempermudah serta meningkatan kinerja.

\section{SARAN}

Penelitian yang bertujuan untuk pengukuran tingkat penerimaan aplikasi SIM3LON (Sistem Mandiri LPG Online) menggunakan TAM (Technology Acceptance Model) ini dapat dikembangkan lebih lanjut dengan menerapkan model lain, seperti contoh Utaut.

\section{UCAPAN TERIMA KASIH}

Penulis mengucapkan terima kasih kepada Tuhan Yang Masa Esa dan juga kepada PT Catur Karya yang telah memberikan izin dan dukungan berupa data terhadap penelitian ini.

\section{DAFTAR PUSTAKA}

[1] Y. Aditya, 2017, Edisi Juni 2017 Volume X No. 2, No. 2, p. 18.

[2] W. A. Subakdo and Y. A. Nugroho, In-Bound dan Out-Bound Logistic pada Distribusi $L P G 3 \mathrm{~kg}$ di Indonesia, p. 10.

[3] E. Fatmawati, Technology Acceptance Model (TAM) Untuk Menganalisis Penerimaan Terhadap Sistem Informasi Perpustakaan, p. 13, 2015. 
[4] F.D, Davis, 1986, A. Technology Acceptance Model for Empirically Testing New and User Information Systems; Theory and Result, Unplublished Ph.D Dissertation Sloan: Sloan School of Management, Massachusetss Institute of Technology (MIT).

[5] Azwar, Saifuddin. 2009, Reliabilitas dan Validitas, Edisi II, Pustaka Pelajar, Yogyakarta

[6] Suyono. 2015, Analisi Regresi untuk Penelitian, Deepublish.

[7] Venkatesh, V. dan Davis, F.D. 2000, A Theoretical Extension of The Technology Acceptance Model: Four Longitudinal Field Studies, Management Science, Vol.46, No.2, hal. 186-204.

[8] Oktavianti, Bramantika. 2007, Evaluasi Penerimaan Sistem Teknologi Informasi dengan Menggunakan Variabel Perceived Usefulness, Perceived Ease of Use, dan Perceived Enjoyment (Studi Kasus: di PT Sanggar Sarana Baja pada Depertemen Accounting dan Marketing), Tesis, Program Studi Magister Sains Akuntasi, Fakultas Ekonomi, Universitas Gadjah Mada, Yogyakarta.

[9] Ghozali, Imam. 2011, Aplikasi Analisis Multivariate Dengan Program IBM SPSS 19, 5th ed, Badan Penerbit Universitas Diponegoro, Semarang.

[10] Sayekti, Fran dan Putarta, Pulasna. 2016, Penerapan Technology Acceptance Model (Tam) Dalam Pengujian Model Penerimaan Sistem Informasi Keuangan Daerah, Jurnal Manajemen Teori dan Terapan, Tahun 9, No.3, Universitas Teknologi Yogyakarta, Yogyakarta. 